\title{
Pengaruh Kualitas Sistem Informasi Akuntansi, Norma Subyektif dan Kemudahan Penggunaan pada Kinerja Individu
}

\author{
Ni Luh Made Galih Putri Saraswati ${ }^{1}$ \\ I Gusti Ayu Eka Damayanthi ${ }^{2}$ \\ ${ }^{1}$ Fakultas Ekonomi dan Bisnis Universitas Udayana (Unud), Bali, Indonesia \\ email: gputri79@gmail.com / Telp:081236144065 \\ ${ }^{2}$ Fakultas Ekonomi dan Bisnis Universitas Udayana (Unud), Bali, Indonesia
}

\begin{abstract}
ABSTRAK
Informasi merupakan salah satu sumber daya bisnis. Kualitas sistem informasi dan keberhasilan perusahaan dipengaruhi oleh kinerja individu. Kinerja individu dengan sistem informasi akuntansi yang berkulitas didukung norma subyektif dan kemudahan penggunaan sistem diharapkan mampu menciptakan kepuasan pengguna sistem informasi, sehingga pemakai mendapatkan manfaat berupa peningkatan kinerja individu. Penelitian ini bertujuan untuk menguji serta memberikan bukti empiris mengenai faktorfaktor yang dapat menyebabkan kesuksesan sistem informasi akuntansi yang berdampak pada peningkatan kinerja individu. Penelitian ini meneliti Perusahaan Oleh-Oleh di Bali dengan mengambil sampel karyawan di Perusahaan Agung Bali Oleh-Oleh berdasarkan teknik non probability sampling dengan metode purposive sampling dan sampel berjumlah 60 karyawan. Pengumpulan data dilakukan dengan metode survey dengan memakai teknik kuisioner dan observasi non participant. Teknik analisis dalam penelitian ini menggunakan analisis Regresi Linier Berganda. Hasil analisis menunjukkan bahwa Kualitas Sistem Informasi Akuntansi (SIA), Norma Subyektif, dan Kemudahan Pemakaian berpengaruh pada Kinerja Individu.

Kata kunci: kualitas SIA, norma subyektif, kemudahan penggunaan, kinerja individu.
\end{abstract}

\begin{abstract}
Information is one of the business resources. Information system quality and company success are influenced by individual performance. The performance of individuals with accounting information systems that are supported by subjective norms and ease of use of the system. This study aims to examine and provide empirical evidence about the factors that can lead to the success of the accounting information system that has an impact on improving individual performance. This study examines souvenir companies in Bali by taking samples of employees at the Bali Agung Company Souvenir based on nonprobability sampling technique with purposive sampling method and a sample of 60 employees. Data collection was carried out using questionnaire and non-participant observation. The analysis technique in this study uses multiple linear regression analysis. The results of the analysis indicate that the Quality of Accounting Information Systems (SIA), Subjective Norms, and Ease of Use have an effect on Individual Performance.

Keywords: SIA quality, subjective norms, ease of use, individual performance
\end{abstract}

\section{PENDAHULUAN}

Informasi merupakan salah satu sumber daya bisnis. Informasi saat ini merupakan sumber daya vital bagi kelangsungan hidup organisasi bisnis. Informasi dikatakan 
Ni Luh Made Galih Putri Saraswati dan I Gusti Ayu Eka Damayanthi. Pengaruh ...

penting dalam bisnis karena akan digunakan sebagai acuan dalam pengambilan keputusan bagi sebuah entitas bisnis. Hall (2009: 8) menyatakan informasi yang baik haruslah relevan, tepat waktu, akurat, dan merupakan rangkuman. Tujuan sebuah informasi yang spesifik dapat berbeda dari satu perusahaan ke perusahaan lain. Hall (2009: 8) menyebutkan tujuan utama informasi adalah untuk mendukung fungsi kepengurusan manajemen, mendukung pengambilan keputusan, dan mendukung kegiatan operasional perusahaan.

Perusahaan atau organisasi bisnis saat ini perlu mengembangkan sistem informasinya agar tidak ketinggalan dalam hal informasi. Pihak yang lebih awal mengetahui informasi adalah pihak yang mampu memenangkan persaingan (Mahendra dan Widhiyani, 2016). Salah satu bentuk informasi yang sering dikatakan sebagai bahasa dunia bisnis, dimana didalamnya menggambarkan mengenai informasi keuangan perusahaan adalah informasi akuntansi. Informasi keuangan merupakan informasi yang berpengaruh dalam pengambilan keputusan sebuah perusahaan. Perkembangan dunia bisnis saat ini menuntut adanya sebuah sistem informasi yang cepat dan akurat yang berguna dalam pengambilan keputusan, maka diperlukanlah sebuah sistem informasi yang mampu menyampaikan informasi tersebut dengan cepat dan akurat kepada pihak yang membutuhkan yaitu dengan sistem informasi akuntansi.

Sistem Informasi Akuntansi merupakan kumpulan sumber daya, seperti manusia dan peralatan, yang dirancang untuk mengubah data keuangan dan data lainnya menjadi sebuah informasi (Bodnar dan Hopwood; 2006, 3). Soudani, 
ISSN: 2302-8556

E-Jurnal Akuntansi Universitas Udayana

Vol.25.2.November (2018): 1339-1368

2012 menyatakan Sistem Informasi Akuntansi (SIA) adalah komponen yang berhubungan dan terintegrasi dalam mengumpulkan, menyimpan, pemrosesan, dan menyebarkan data untuk tujuan pengambilan keputusan. Penerapan sistem informasi akuntansi akan memberikan kemudahan bagi pemakai sistem sehingga mampu menghasilkan informasi yang akurat, terpercaya, tepat waktu dan relevan (Grande, 2011). Romney dan Steinbart (2015; 7) menyatakan penerapan Sistem Informasi Akuntansi mampu meningkatkan kualitas dan mengurangi biaya produk atau jasa, meningkatkan efisiensi, berbagi pengetahuan, meningkatkan efisiensi dan efektivitas rantai pasokannya, meningkatkan struktur pengendalian internal, dan mampu membantu pengambilan keputusan yang tepat.

Sistem Informasi Akuntansi dalam perkembangannya dapat menjadi sistem manual hingga sistem yang kompleks dimana menggunakan teknologi informasi terbaru, atau percampuran diantara keduanya. Perkembangan Sistem Informasi Akuntansi dari manual hingga menggunakan teknologi informasi atau kombinasi keduanya, tentunya didukung oleh perkembangan dari teknologi informasi itu sendiri. Perkembangan teknologi informasi yang terjadi tidak hanya mempengaruhi dunia bisnis saja akan tetapi juga mempengaruhi berbagai bidang dalam kehidupan bermasyarakat. Perkembangan teknologi yang sangat pesat meliputi perkembangan infrastruktur teknologi informasi, seperti perkembangan hardware, software, teknologi penyimpanan, dan teknologi komunikasi. Perkembangan tersebut menyebabkan banyak perusahaan yang mulai menerapkan teknologi dalam kegiatan operasionalnya. 
Ni Luh Made Galih Putri Saraswati dan I Gusti Ayu Eka Damayanthi. Pengaruh ...

Pengadopsian teknologi informasi banyak dilakukan oleh perusahaan saat ini dengan harapan mampu meningkatkan kinerja perusahaan. Penggunaan sistem informasi akuntansi yang didukung oleh pemanfaatan teknologi informasi dan pemakai sistem yang baik mampu mendorong perusahaan untuk mencapai keunggulan kompetitif (Pardani dan Damayanthi, 2017). Dewi dan Dharmadiaksa (2017) menyatakan perusahaan yang bekerja dengan teknologi yang canggih (terkomputerisasi dan terintegrasi) diharapkan mampu berdampak positif bagi kinerja perusahaan. Pemanfaatan teknologi informasi dalam perusahaan juga dapat meningkatkan pelayanan administrasi, serta membantu dalam pengambilan keputusan (Anwar, 2009).

Sistem Informasi Akuntansi yang dipadukan dengan teknologi informasi dikatakan berhasil apabila dapat mempermudah serta miningkatkan kinerja individu atau pemakai sistem informasi tersebut. Sistem informasi tidak dapat dikatakan berhasil tanpa dukungan dari penggunanya dalam hal ini adalah sumber daya manusianya. Sumber daya manusia atau karyawan merupakan aset penting sebuah perusahaan, karena melalui kinerja individual karyawan tersebut tujuan perusahaan dicapai. Kinerja individual merupakan kemampuan individu dalam menyelesaikan tugasnya dengan berhasil. Dewi dan Dharmadiaksa (2017 berpendapat teknologi informasi dapat dimanfaatkan secara efektif sehingga dapat memberi kontribusi bagi kinerja individual.

Penerapan dari sebuah sistem informasi baik yang manual maupun berbasis teknologi memberikan dua dampak yaitu keberhasilan sistem atau 
ISSN: 2302-8556

E-Jurnal Akuntansi Universitas Udayana

Vol.25.2.November (2018): 1339-1368

kegagalan sistem (Mahendra dan Widhiyani, 2016). Keberhasilan atau kesuksesan suatu sistem dapat dilihat dari beberapa faktor didalamnya. Delone dan Mclean (1992) meneliti beberapa faktor kesuksesan sistem informasi, salah satunya adalah kualitas sistem, kualias informasi, penggunaan, kepuasan pemakai, dan dampak individu, dan dampak organisasi. Hasil penelitian Delone dan Mclean dapat dijelaskan bahwa kualitas sistem (system quality) dan kualitas informasi (information quality) secara mandiri dan bersama-sama mempengaruhi baik penggunaan (use) dan kepuasan pemakai (user satisfaction). Besarnya penggunaan (use) dapat mempengaruhi kepuasan pemakai (user satisfaction) secara positif atau negatif. Penggunaan (use) dan kepuasan pemakai (user satisfaction) mempengaruhi dampak individual (individual impact) dan selanjutnya mempengaruhi dampak organisasional (organizational impact). Pada tahun 2003 Delone dan Mclean memperbaharui model kesuksesannya dengan menambahkan kualitas pelayanan, minat pemakai serta menggabungkan dampak individu dan organisasi menjadi manfaat yang didapatkan.

Keberhasilan maupun kegagalan dari sebuah sistem terlihat dari kepuasan pemakai sistem informasi tersebut. Sistem yang berkualitas dengan didukung norma subyektif dan kemudahan dalam penggunaan mampu meningkatkan keinginan dalam menggunakan sistem tersebut, yang kemudian menciptakan kepuasan pemakai sistem dalam menggunakan sistem tersebut. Delone dan Mclean (1992) menyatakan bahwa penggunaan sistem informasi berbasis 
Ni Luh Made Galih Putri Saraswati dan I Gusti Ayu Eka Damayanthi. Pengaruh ...

teknologi informasi dan kepuasan pemakai dapat meningkatkan kinerja perusahaan maupun kinerja individu pemakai sistem tersebut.

Globalisasi yang terjadi mengakibatkan berkembangnya berbagai bidang kehidupan didunia. Perkembangan yang terjadi tidak hanya mengenai teknologi informasi, perekonomian, sosial, dan budaya saja, sektor pariwisata juga mengalami perkembangan yang pesat. Perkembangan ini terjadi karena meningkatnya kebutuhan untuk menikmati hiburan dan adanya kemajuan dibidang transportasi dan teknologi komunikasi. Pariwisata memiliki peranan penting dalam suatu Negara, baik sebagai salah satu sumber penerimaan devisa bagi Negara maupun sebagai pencipta lapangan kerja serta kesempatan berusaha. Industri ini juga merupakan salah satu industri terbesar dan merupakan sektor jasa dengan tingkat pertumbuhan paling pesat didunia saat ini. Sektor ini dirasakan memberikan kontribusi positif dalam memacu menggerakkan sektor perekonomian lainnya.

Pulau Bali adalah sebuah pulau kecil yang memiliki daya tarik berupa keindahan alam dan budaya yang sangat kental dalam kehidupan sehari hari masyarakat Bali. Berbagai macam cindramata berbau seni yang bernuansa budaya Bali yang khas tentunya menjadi hal yang diburu wisatawan sebelum kembali ke Negara atau Daerahnya masing-masing. Kebutuhan akan barang oleh-oleh saat liburan di Bali, menyebabkan sejumlah toko oleh-oleh yang berkonsepkan wisata belanja bermunculan di Bali. Agung Bali Oleh-Oleh dipilih sebagai sampel untuk mewakili Perusahaan Oleh-Oleh di Bali karena merupakan salah satu wisata 
belanja tujuan wisatawan saat datang ke Bali. Hal ini ditandai dengan berkembangnya perusahaan ini sejak 2003 hingga sekarang sudah memiliki tiga cabang perusahaan yang terletak di Tanah Lot, Sunset Road, dan Jalan Dewi Sri Kuta. Semakin tingginya minat wisatawan untuk berkunjung atau berwisata ke Pulau Bali, tentunya harus disikapi oleh pihak perusahaan sendiri dalam penyediaan layanan yang mampu memberi kepuasan bagi pelanggan. Perusahaan ini memiliki kegiatan yang cukup kompleks, sehingga membutuhkan sebuah sistem yang mampu mengatur agar mampu menciptakan kinerja yang baik bagi karyawan maupun bagi perusahaan.

Agung Bali Oleh-Oleh sudah mengadopsi sistem informasi akuntansi berbasis komputer dalam kegiatan operasional perusahaannya, namun sebelumnya sistem yang digunakan hanya teknologi respons cepat berupa Universal Product Code (UPC) yang digunakan untuk memudahkan dalam penjualan barang yang langsung terintegrasi dengan jumlah persediaan. Sistem Informasi yang ada hanya melibatkan beberapa unit pekerjaan terutama kasir. Sistem pembuatan laporan pun masih berupa laporan manual yang dikumpulkan oleh masing-masing kantor cabang dan dilaporkan ke kantor pusat yang berada di Tanah Lot setiap satu minggu sekali. Cara pelaporan seperti ini menyebabkan seringnya terjadi keterlambatan informasi dan kesulitan dalam pengambilan keputusan jangka pendek. Dalam rangka peningkatan produktivitas dan kinerja perusahaan mulai awal April tahun 2017 mulai diterapkan beberapa SIA tambahan seperti Sistem komputasi pengguna akhir (EUC) yang digunakan dalam mempermudah 
Ni Luh Made Galih Putri Saraswati dan I Gusti Ayu Eka Damayanthi. Pengaruh ...

pembuatan laporan, email, Computer Aided Design (CAD) yang digunakan dalam mendesain produk dagangan berupa baju kaos, menerima EFT (electronic fund transfer) sebagai alat pembayaran, serta menggunakan finger print dalam absen karyawan yang langsung terintegrasi dengan SAP R/3 yaitu model yang berisikan data karyawan dan struktur organisasi. Penggunaan SIA berbasis komputer ini diharapkan akan mampu memudahkan pemakai dalam melakukan kinerjanya.

Penerapan SIA baru di Perusahaan Agung Bali Oleh-Oleh yang sudah berjalan beberapa bulan ini, berdasarkan atas observasi awal yang telah dilakukan oleh peneliti, menurut owner Agung Bali Oleh-Oleh Anak Agung Arimbawa dalam prakteknya tidak sedikit karyawan yang tidak percaya diri dalam menggunakan SIA yang ada, hal ini mungkin dikarenakan kurangnya pendidikan dalam penggunaan komputer, dimana sebelumnya mereka terbiasa bekerja dengan proses manual. Melihat penerapan SIA di perusahaan Agung Bali Oleh-Oleh tersebut, maka akan dilihat faktor-faktor kesuksesan sistem informasi apakah penerapan sistem informasi akuntansi yang baru dapat dikatakan sukses atau berhasil yang dilihat dari peningkatan kinerja kinerja karyawan.

Penelitian ini mengadopsi penelitian DeLone dan McLean (1992) dengan penelitiannya yang berjudul Information Sistem Success : The Quest for the Dependent Variable. Delone dan McLean mencoba untuk membangun suatu taksonomiyang terdiri atas enam dimensi keberhasilan sistem informasi, yakni kualitas sistem (system quality), kualitas informasi (information quality), penggunaan (use), kepuasan pengguna (User Satisfaction), dampak individu 
ISSN: 2302-8556

E-Jurnal Akuntansi Universitas Udayana

Vol.25.2.November (2018): 1339-1368

(individual impact), dan dampak organisasional (organizational impact). Hasil penelitian Delone dan McLean menunjukkan bahwa, di antara enam kategori yang membangun keberhasilan sistem informasi ini, terdapat suatu keterkaitan dan ketergantungan yang kemudian menentukan berhasil tidaknya penerapan suatu sistem informasi.

Hasil penelitian DeLone dan McLean salah satunya menyatakan bahwa kualitas sistem mempengaruhi penggunaan dan kepuasan pengguna, yang kemudian jumlah penggunaan dan kepuasan pengguna akan berdampak dengan kinerja individu. Penelitian ini menjadikan kualitas sistem informasi akuntansi sebagai variabel untuk diteliti kembali apakah hasil yang didapat akan konsisten pada Perusahaan Oleh-Oleh yang ada di Bali. Penggunaan sistem hingga berdampak kepada kepuasan pengguna dan peningkatan kinerja tentunya didukung oleh faktor-faktor tertentu. Ada banyak faktor yang dapat mempengaruhi kepuasan pengguna akan sistem yang digunakan dan kinerja individu. Norma subyektif dan kemudahan penggunaan dipilih sebagai variabel yang akan diteliti untuk mengetahui faktor apakah yang mempengaruhi minat seseorang dalam penggunaan suatu sistem informasi akuntansi.

Tujuan penelitian ini yaitu: 1) Untuk menganalisis pengaruh Kualitas Sistem Informasi Akuntansi terhadap Kinerja Individu di Perusahaan Agung Oleh-Oleh Bali; 2) Untuk menganalisis pengaruh Norma Subyektif terhadap Kinerja Individu di Perusahaan Agung Oleh-Oleh Bali; 3) Untuk menganalisis 
Ni Luh Made Galih Putri Saraswati dan I Gusti Ayu Eka Damayanthi. Pengaruh ...

pengaruh Kemudahan Penggunaan terhadap Kinerja Individu di Perusahaan Agung Oleh-Oleh Bali.

Penelitian ini dapat memberikan kontribusi dalam Information System Success Model, Teori Technology Acceptance Model (TAM), dan Theory of Reasoned Action (TRA). sehingga dapat dijadikan perbandingan, pengembangan, dan penyempurnaan dari penelitian-penelitian yang telah dilakukan sebelumnya. Selain itu, penelitian ini diharapkan dapat memberikan tambahan referensi bagi pengembangan ilmu pengetahuan, khususnya memberikan pemahaman yang lebih luas mengenai pengaruh penerapan Sistem Informasi Akuntansi, Kecanggihan Teknologi Informasi, dan Kemampuan Teknik Pemakai terhadap Kinerja Individu.

Delone dan Mclean (1992) melakukan penelitian yang bertujuan untuk mengetahui aspek-aspek yang mempengaruhi kesuksesan sistem informasi. Berdasarkan teori-teori dan hasil penelitian sebelumnya yang telah dikaji, DeLone dan McLean kemudian mengembangkan suatu model parsimoni yang mereka sebut dengan nama model kesuksesan sistem informasi DeLone \& McLean $(D \& M$ Information System Success Model). Model ini menjelaskan bahwa pengukuran kesuksesan sistem informasi dikategorikan dalam enam kategori yaitu kualitas sistem (system quality), kualitas informasi (information quality), penggunaan (use), kepuasan pegguna (User Satisfaction), dampak individu (individual impact), dan dampak organisasional (organizational impact). 
ISSN: 2302-8556

E-Jurnal Akuntansi Universitas Udayana

Vol.25.2.November (2018): 1339-1368

Technology Acceptance Model (TAM) adalah model yang disusun oleh Davis (1986) untuk menjelaskan factor-faktor utama dari perilaku pengguna teknologi informasi untuk menerima dan menggunakan teknologi. Teori ini berasal dari sebuah teori induk dibidang kajian keyakinan, sikap dan perilaku yang diformulasikan oleh Fishbein dan Ajzen (1975) dengan nama Theory of Reasoned Action (TRA) atau teori tindakan beralasan. TRA disusun menggunakan asumsi dasar bahwa manusia berperilaku dengan cara yang sadar dan mempertimbangkan segala informasi yang tersedia. Ajzen (1980) menyatakan bahwa niat seseorang untuk melakukan suatu perilaku menentukan akan dilakukan atau tidak dilakukannya perilaku tersebut. Ramdhani (2009) munyatakan terdapat tiga variable dasar dalam TRA yaitu perilaku, norma subjektif, dan keyakinan. Teori TAM ini tidak mengakomodasi semua komponen teori TRA, Davis hanya memanfaatkan komponen keyakinan dan sikap saja, sedangkan keyakinan normatif dan norma subjektif tidak digunakan.

Theory of Reasoned Action (TRA) atau sering disebut juga teori tindakan beralasan pertama kali dicetuskan oleh Ajzen pada tahun 1980 (Jogiyanto, 2007). Teori ini disusun menggunakan asumsi dasar bahwa manusia berperilaku dengan cara yang sadar dan mempertimbangkan segala informasi yang tersedia. Ajzen (1980) menyatakan bahwa niat seseorang untuk melakukan suatu perilaku menentukan akan dilakukan atau tidak dilakukannya perilaku tersebut. Ramdhani (2009) munyatakan terdapat tiga variabel dasar dalam TRA yaitu perilaku, norma subjektif, dan keyakinan. 
Ni Luh Made Galih Putri Saraswati dan I Gusti Ayu Eka Damayanthi. Pengaruh ...

Sistem Informasi Akuntansi merupakan sekumpulan sumber daya yang dirancang untuk mentransformasi data menjadi informasi yang digunakan dalam pengambilan keputusan. Penerapan sistem informasi akuntasi merupakan kualitas dari kombinasi antara hardware dan software dalam suatu sistem informasi, yang ditunjukan dengan performa dari suatu sistem yang menunjukan seberapa baik kemampuan perangkat keras, perangkat lunak, kebijakan, dan prosedur dari suatu sistem informasi dapat menyediakan informasi kebutuhan penggunanya (Dita dan Putra, 2016).

Penerapan sistem informasi yang digunakan secara berulang-ulang dapat mengartikan bahwa pengguna puas menggunakan sistem tersebut. Michael G. Alles, et al (2008) menyatakan SIA dapat menambah keunggulan komparatif untuk nilai tambah SIA dengan penerapan secara bertahap sesuai dengan karateristik industri dan kemampuan serta keterampilan menggunakan SIA. Penelitian yang dilakukan Al-Kasswna (2012) mengenai Penerapan Sistem Informasi Akuntansi di Pemerintahan Kerajaan Yordania menemukan penerapan SIA mampu memenuhi kebutuhan berbagai pihak dan manajemen pemerintahan. Kharuddin (2010), Alrabei (2014), dan Lesmana (2014) juga menyimpulkan penerapan Sistem Informasi Akuntansi berpengaruh positif terhadap kinerja individu. Sistem informasi yang berkualitas mampu memberikan dampak positif terhadap kinerja individu. Berdasarkan penjelasan tersebut dapat dikembangkan hipotesis penelitian sebagai berikut:

$\mathrm{H}_{1} \quad \quad$ Kualitas Sistem Informasi Akuntansi berpengaruh positif terhadap kinerja individu. 
ISSN: 2302-8556

E-Jurnal Akuntansi Universitas Udayana

Vol.25.2.November (2018): 1339-1368

Penerapan Sistem Informasi Akuntansi (SIA) sebelum terjadi kemajuan teknologi masih secara manual. Individu dalam organisasi melakukan pencatatan, pemrosesan data, dan penggunaan informasi secara manual, namun dengan perkembangan teknologi informasi banyak perusahaan mulai mengadopsi penerapan sistem informasi akuntansi berbasis teknologi. Pengadopsian SIA berbasis teknologi diharapkan dapat meningkatkan produktifitas perusahaan pada umumnya dan karyawan pada khususnya, seperti penelitian yang dilakukan Lee J Yao, et al (2010) yang menemukan karakteristik perusahaan memoderasi dampak positif penerapan teknologi informasi pada produktivitas perusahaan.

Peningkatan produktivitas atau kinerja individu akan terjadi apabila individu tersebut mau menggunakan sistem informasi akuntansi yang ada dan merasa puas dan terbantu dengan sistem tersebut. Niat seseorang untuk melakukan sesuatu timbul sesuai dengan Theory of Reasoned Action (TRA) yang mengasumsikan bahwa manusia berprilaku dengan cara yang sadar dan mempertimbangkan segala informasi yang tersedia. TRA merupakan teori tindakan beralasan dimana salah satu faktor yang mempengaruhi seseorang dalam berprilaku adalah norma subyektif.

Norma-norma subyektif ( subjective norms ) adalah pengaruh sosial yang mempengaruhi seseorang untuk berperilaku. Seseorang akan memiliki keinginan terhadap suatu obyek atau perilaku seandainya ia terpengaruh oleh orang-orang di sekitarnya untuk melakukannya atau ia meyakini bahwa lingkungan atau orangorang disekitarnya mendukung terhadap apa yang ia lakukan. Thompson et al 
Ni Luh Made Galih Putri Saraswati dan I Gusti Ayu Eka Damayanthi. Pengaruh ...

(1991) menemukan bahwa Norma Subyektif memiliki pengaruh yang signifikan terhadap pemanfaatan komputer yang konsisten. Rahmi Qadri (1997) dan Thai Fung Jin (2002) menemukan bahwa terdapat hubungan yang positif dan signifikan antara norma subyektif dengan pemanfaatan sistem informasi berbasis teknologi. Berdasarkan penjelasan tersebut dapat dikembangkan hipotesis penelitian sebagai berikut:

$\mathrm{H}_{2}$ : Norma subyektif berpengaruh positif terhadap kinerja individu.

Sebuah sistem yang baik tidak dapat berjalan sesuai fungsinya tanpa adanya pemakai atau pengguna. Sistem informasi tidak dapat terlepas dari individu yang mengoperasikannya. Fungsi dari sistem akan maksimal apabila pemakai mampu menggunakan sistem tersebut dengan baik. Pardani dan Damayanthi (2017) menyatakan pentingnya penggunaan sistem informasi akuntansi yang didukung oleh pemanfaatan teknologi informasi dan pemakai sistem yang baik mendorong sebuah organisasi untuk menciptakan keunggulan kompetitif.

Perkembangan sistem informasi para pemakai menjadi fokus dalam keefektivan penggunaan SIA. Sistem yang canggih dan sudah didesain sedemikian rupa tidak akan mampu memberikan manfaat apabila tidak mudah digunakan. Kemudahan dalam penggunaan dapat dikaitkan dengan kemampuan yang dimiliki pengguna. Kemampuan teknik pemakai yang baik sangat diharapkan akan meningkatkan kinerja dari sistem dan tentunya meningkatkan kinerja individu secara langsung maupun tidak langsung. Pemakai yang handal 
serta mengetahui perkembangan teknologi akan mampu menghasilkan informasi yang tepat waktu dan handal. Dewi dan Dharmadiaksa, (2017) melakukan penelitian mengenai pengaruh kemampuan teknik pemakai terhadap kinerja individu di Koperasi Simpan Pinjam di Karangasem menyatakan kemampuan teknik pemakai mampu meningkatkan kinerja individu pada Koperasi Simpan Pinjam di Kabupaten Karangasem. Alannita dan Suaryana (2014) dan Mahendra dan Widhiani (2016) juga menemukan kemampuan teknik pemakai berpengaruh positif terhadap kinerja karyawan. Berdasarkan penjelasan tersebut dapat dikembangkan hipotesis penelitian sebagai berikut:

$\mathrm{H}_{3}$ : Kemampuan Teknik Pemakai berpengaruh positif terhadap kinerja individu.

\section{METODE PENELITIAN}

Penelitian ini membahas tentang pengaruh kualitas sistem informasi akuntansi, norma subyektif, dan kemudahan penggunaan pada kinerja individu di Perusahaan Agung Bali Oleh-Oleh. Bentuk pendekatan yang digunakan pada penelitian ini adalah pendekatan bersifat asosiatif. Penelitian asosiatif merupakan dugaan tentang adanya hubungan antar variabel dalam populasi yang akan diuji melalui hubungan antar variabel dalam sampel yang diambil dari populasi tersebut (Sugiyono, 2016; 211). Objek penelitian yang digunakan dalam penelitian ini adalah kineja individu di Perusahaan Agung Bali Oleh-Oleh.

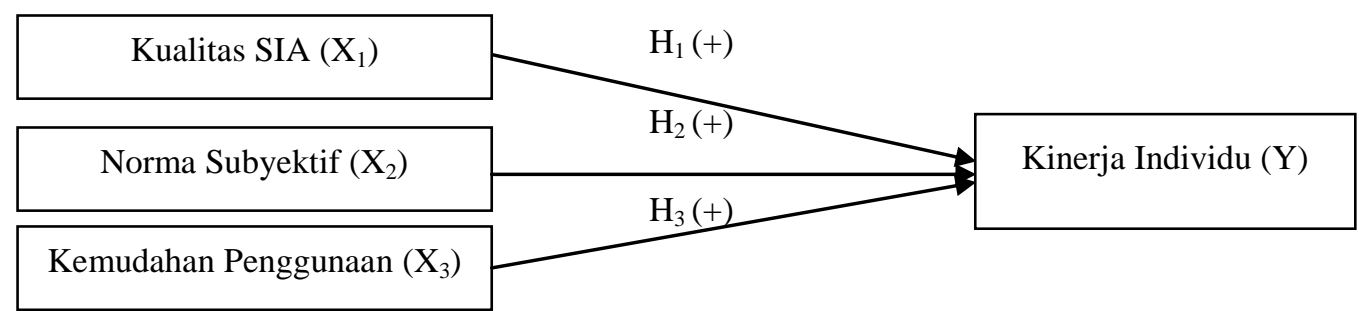

Gambar 1. Desain Penelitian 
Ni Luh Made Galih Putri Saraswati dan I Gusti Ayu Eka Damayanthi. Pengaruh ...

Variabel bebas merupakan variabel yang mempengaruhi atau yang menjadi sebab perubahannya atau timbulnya variabel terikat atau dependen (Sugiyono, 2016;4). Variabel bebas dalam penelitian ini yaitu kualitas Sistem Informasi Akuntansi (X1), norma subyektif (X2), dan kemudahan penggunaan (X3). DeLone dan McLean (1992) menyatakan kualitas sistem yaitu karakteristik dari informasi yang melekat mengenai sistem itu sendiri. Penerapan sistem informasi akuntansi berkualitas merupakan sebuah pengaplikasian sistem yang terdiri dari kumpulan sumber daya, baik sumber daya manusia maupun sumber daya lainnya yang terorganisir dengan baik, serta diharapkan akan mampu memaksimalkan kinerja.

Norma Subyektif merupakan persepsi seseorang mengenai tekanan sosial untuk melakukan atau tidak melakukan sesuatu. Seseorang akan memiliki keinginan terhadap suatu objek atau prilaku apabila terdapat dukungan dari lingkungan sekitar terhadap apa yang seseorang lakukan. Norma sosial mendukung individu dalam perusahaan untuk menggunakan sistem informasi akuntansi yang berbasis teknologi dalam kegiatan operasionalnya yang kemudian mempengaruhi kinerja individu tersebut.

Kemudahan penggunaan sebuah sistem informasi akuntansi berbasis teknologi didefinisikan sebagai suatu ukuran dimana seseorang percaya bahwa komputer dapat dengan mudah dipahami dan digunakan. Kepercayaan ini menentukan suatu sikap pemakai ke arah penggunaan suatu sistem kemudian 
menentukan niat tingkah laku dan mengarah pada penggunaan sistem secara nyata.

Variabel terikat merupakan variabel yang dipengaruhi atau yang menjadi akibat, karena adanya variabel bebas (Sugiyono, 2016;4). Variabel terikat dalam penelitian ini adalah kinerja karyawan di Perusahaan Agung Bali Oleh-Oleh, yang diukur dengan 5 indikator yaitu kuantitas kerja, kualitas kerja, ketepatan waktu, pengawasan supervisor, pengaruh rekan kerja. Variabel-variabel dalam penelitian ini disajikan dalam bentuk penyataan dan diukur menggunakan 4 Skala likert dari setuju sampai tidak setuju yaitu 1 berarti sangat tidak setuju (STS), 2 berarti tidak setuju (TS), 3 berarti setuju (S), dan 4 berarti sangat setuju (SS).

Jenis data yang digunakan dalam penelitian ini adalah data kualitatif dan data kuantitatif. Data kualitatif berupa gambaran umum mengenai Agung Bali Oleh-Oleh. Data kuantitatif yang digunakan dalam penelitian ini berupa data skor jawaban kuisioner dari responden.

Menurut sumbernya data yang digunakan dalam penelitian ini adalah data primer dan data sekunder. Data primer adalah data yang didapat secara langsung dari lokasi penelitian, dimana data primer dalam penelitian ini yaitu hasil kuisioner atau jawaban dari responden. Data sekunder adalah sumber yang tidak langsung memberikan sumber data kepada pengumpul data. Data sekunder dalam penelitian didapat dari Perusahaan Agung Bali Oleh-Oleh berupa struktur organisasi, data jumlah karyawan, dan gambaran umum perusahaan. 
Ni Luh Made Galih Putri Saraswati dan I Gusti Ayu Eka Damayanthi. Pengaruh ...

Populasi adalah wilayah generalisasi yang terdiri atas objek atau subjek yang mempunyai kualitas dan karakteristik tertentu yang ditetapkan oleh peneliti untuk dipelajari dan kemudian ditarik kesimpulannya (Sugiyono, 2016;61). Populasi dalam penelitian ini adalah seluruh karyawan di Perusahaan Agung Bali Oleh-Oleh yang berjumlah 190 orang. Teknik pengambilan sampel yang digunakan dalam penelitian ini adalah teknik non probability sampling dengan metode purposive sampling. Adapun kriteria yang dijadikan dasar pemilihan anggota sampel pada penelitian ini adalah karyawan yang berkerja berkaitan dengan Sistem Informasi Akuntansi, kriteria ini dipilih dengan maksud mendapatkan hasil yang sesuai dengan variabel yang akan diteliti, seperti meneliti karyawan yang benar-benar bekerja menggunakan sistem informasi akuntansi dan professional di bidangnya (Dewi dan Dharmadiaksa, 2017). Berdasarkan kriteria, diperoleh sampel penelitian sejumlah 60 orang.

Metode pengumpulan data yang digunakan dalam penelitian ini adalah metode survey dengan memakai teknik kuisioner dan observasi non participant. Teknik analisis data yang digunakan adalah analisis regresi linier berganda. Analisis regresi linier berganda digunakan untuk meramalkan keadaan (naik turun) variable dependen, bila dua atau lebih variabel independen sebagai faktor prediktor dimanipulasi (dinaik turunkan nilainya). Teknik analisis ini dinyatakan dalam model persamaan berikut:

$Y=\alpha+\beta_{1} X_{1}+\beta_{2} X_{2}+\beta_{3} X_{3}+\varepsilon$

Keterangan :

Y = kinerja individu Perusahaan Agung Bali Oleh-Oleh 


$$
\begin{array}{ll}
\alpha & =\text { konstanta } \\
\beta_{1}, \beta_{2}, \beta_{3} & =\text { koefisien regresi } \\
X_{1} & =\text { kualitas Sistem Informasi Akuntansi } \\
X_{2} & =\text { norma subyektif } \\
X_{3} & =\text { kemudahan penggunaan }
\end{array}
$$

\section{HASIL DAN PEMBAHASAN}

Penelitian ini dilakukan untuk mengetahui pengaruh Kualitas Sistem Informasi Akuntansi, Norma Subyektif dan Kemudahan Penggunaan pada Kinerja Individu di Perusahaan Agung Bali Oleh-Oleh. Data dalam penelitian ini dikumpulkan melalui penyebaran kuesioner ke Perusahaan Agung Bali Oleh-Oleh, dengan jumlah sampel penelitian yaitu 60. Jumlah kuesioner yang disebar adalah sebanyak 60 eksemplar.

Berdasarkan seluruh jumlah kuesioner yang disebarkan, kuesioner yang kembali dan telah diisi secara lengkap sesuai dengan kriteria sebanyak 60 eksemplar dan tidak ada kuesioner yang tidak kembali. Ringkasan distribusi kuesioner penelitian disajikan dalam Tabel 1. berikut yaitu:

Tabel 1.

Data Penyebaran dan Pengembalian Kuesioner

\begin{tabular}{lcc}
\hline \multicolumn{1}{c}{ Uraian } & Jumlah Kuesioner & Persentase \\
\hline Total kuesioner yang disebar & 60 & $100 \%$ \\
Kuesioner yang kembali & 60 & $100 \%$ \\
Kuesioner yang tidak kembali & - & $0 \%$ \\
Kuesioner yang dapat diolah & 60 & $100 \%$ \\
\hline Sumber: Data diolah, 2018
\end{tabular}

Sumber: Data diolah, 2018

Ghozali $(2016 ; 19)$ menyatakan statistik deskriptif memberikan informasi mengenai karakteristik variabel penelitian yang terdiri atas jumlah pengamatan, nilai minimum, nilai maksimum, nilai mean dan standar deviasi. Tabel 2. menunjukan hasil uji statistik deskriptif. 
Tabel 2.

Hasil Uji Statistik Deskriptif

\begin{tabular}{lccccc}
\hline \multicolumn{1}{c}{ Variabel } & $\begin{array}{c}\text { Jumlah } \\
\text { Sampel }\end{array}$ & $\begin{array}{c}\text { Nilai } \\
\text { Minimum }\end{array}$ & $\begin{array}{c}\text { Nilai } \\
\text { Maksimum }\end{array}$ & Mean & $\begin{array}{l}\text { Standar } \\
\text { Deviasi }\end{array}$ \\
\hline Kualitas SIA (X1) & 60 & 6,39 & 19,35 & 14,7875 & 4,19830 \\
$\begin{array}{l}\text { Norma SUbyektif } \\
\text { (X2) }\end{array}$ & 60 & 7,55 & 22,89 & 18,0917 & 5,06317 \\
$\begin{array}{l}\text { Kemudahan } \\
\text { Penggunaan (X3) }\end{array}$ & 60 & 3,00 & 11,19 & 8,5915 & 2,62872 \\
Kinerja Individu (Y) & 60 & 6,35 & 19,22 & 14,8090 & 4,20218 \\
\hline Sumber: Data diolah, 2018 & & & & &
\end{tabular}

Tabel 2. menunjukan bahwa variabel Kualitas Sistem Informasi Akuntansi $\left(X_{1}\right)$ memiliki nilai minimum sebesar 6,39, nilai maksimum sebesar 19,35, mean sebesar 14,8 dan standar deviasi sebesar 4,20. Nilai rata-rata sebesar 14,8 menunjukkan bahwa respon responden dalam menjawab pertanyaan pada kuisioner cenderung setuju pada masing-masing item pertanyaan artinya kualitas sistem informasi akuntansi cenderung tinggi mendekati nilai maksimum, yang menunjukkan bahwa kualitas SIA yang diterapkan di perusahaan Agung Bali Oleh-Oleh dapat dikatakan baik. Standar deviasi pada Penerapan Sistem Informasi Akuntansi adalah sebesar 4,20. Hal ini menunjukkan bahwa standar penyimpangan data terhadap nilai rata-ratanya adalah 4,20.

Variabel Norma Subyektif $\left(\mathrm{X}_{2}\right)$ memiliki nilai minimum sebesar 7,55, nilai maksimum sebesar 22,89, mean sebesar 18,10 dan standar deviasi sebesar 5,10. Nilai rata-rata sebesar 18,10 menunjukkan bahwa respon responden dalam menjawab pertanyaan pada kuisioner cenderung setuju pada masing-masing item pertanyaan artinya norma subyektif cenderung tinggi mendekati nilai maksimum, yang menunjukkan bahwa reponden responden mendapat dukungan dari lingkungan sekitar untuk menggunakan sistem yang berbasis teknologi dalam 
kegiatan operasional di perusahaan Agung Bali Oleh-Oleh. Standar deviasi pada norma subyektif adalah sebesar 5,10. Hal ini menunjukkan bahwa standar penyimpangan data terhadap nilai rata-ratanya adalah 5,10

Variabel Kemudahan Penggunaan $\left(\mathrm{X}_{3}\right)$ memiliki nilai minimum sebesar 3,00, nilai maksimum sebesar 11,19, mean sebesar 8,60 dan standar deviasi sebesar 2,63. Nilai rata-rata sebesar 18,10 menunjukkan bahwa respon responden dalam menjawab pertanyaan pada kuisioner cenderung setuju pada masingmasing item pertanyaan artinya kemudahan penggunaan cenderung tinggi mendekati nilai maksimum, yang menunjukkan bahwa reponden cenderung memiliki kemampuan teknik pemakai dalam mengoperasionalkan sistem dan teknologi yang digunakan di perusahaan Agung Bali Oleh-Oleh yang menunjukkan kemudahan penggunaan. Standar deviasi pada kemudahan penggunaan adalah sebesar 2,63. Hal ini menunjukkan bahwa standar penyimpangan data terhadap nilai rata-ratanya adalah 2,63.

Variabel Kinerja Individu (Y) memiliki nilai minimum sebesar 6,35, nilai maksimum sebesar 19,22, mean sebesar 14,81 dan standar deviasi sebesar 4,20. Nilai rata-rata sebesar 14,81 menunjukkan bahwa respon responden dalam menjawab pertanyaan pada kuisioner cenderung setuju pada masing-masing item pertanyaan artinya kinerja individu cenderung tinggi mendekati nilai maksimum, yang menunjukkan bahwa reponden cenderung terjadi peningkatan kinerja dengan penerapa sistem infomasi akuntansi dalam operasional perusahaan Agung Bali Oleh-Oleh. Standar deviasi pada kinerja individu adalah sebesar 4,20. Hal ini 
Ni Luh Made Galih Putri Saraswati dan I Gusti Ayu Eka Damayanthi. Pengaruh ...

menunjukkan bahwa standar penyimpangan data terhadap nilai rata-ratanya adalah 4,20 .

Instrument dikatakan valid apabila instrument yang digunakan dalam penelitian mampu untuk mengukur apa yang hendak diukur. Pengujian validitas dilakukan dengan menghitung nilai pearson correlation. Suatu instrumen akan dikatakan valid apabila nilai $\mathrm{r}$ pearson correlation terhadap skor total diatas 0,30 (Ghozali, 2016;55). Berdasarkan hasil uji validitas pada penelitian ini variabel Kualitas SIA, Norma Subyektif, Kemudahan Penggunaan dan Kinerja Individu memiliki nilai pearson correlation lebih dari 0,30 . Hal ini menunjukan bahwa pernyataan dalam kuesioner telah memenuhi syarat valid.

Pengujian reliabilitas menunjukan seberapa besar suatu alat pengukur dapat dipercaya atau diandalkan. Uji ini dilakukan terhadap instrument dengan koefisien Cronbach's Alpha. Apabila nilai koefisiennya lebih besar dari 0,70 maka instrumen yang digunakan reliabel (Ghozali, 2016;48). Berdasarkan hasil uji reliabilitas pada penelitian ini ketiga instrumen penelitian memiliki koefisien Cronbach's Alpha lebih besar dari 0,70 sehingga pernyataan dalam kuesioner tersebut reliabel.

Pengujian dengan menggunakan teknik analisis regresi berganda diawali dengan pengujian asumsi klasik terlebih dahulu, agar hasil pengujian yang bias dapat dihindari. Model regresi yang baik adalah model regresi yang di dalamnya tidak terdapat masalah data yang distribusinya normal, masalah multikolinearitas dan masalah heteroskedastisitas. Uji normalitas bertujuan untuk menguji apakah 
ISSN: 2302-8556

E-Jurnal Akuntansi Universitas Udayana

Vol.25.2.November (2018): 1339-1368

dalam residual dari model regresi yang dibuat berdistribusi normal ataukah tidak (Utama:2014). Hasil uji normalitas penelitian ini menunjukan bahwa nilai Asymp, Sig. (2-tailed) dalam penelitian ini $>0,05$. Hal ini berarti seluruh variabel dalam penelitian ini berdistribusi normal.

Uji heteroskedasitas bertujuan unyuk menguji apakah model regresi terjadi ketidaksamaan varians dari residual pengamatan ke pengamatan yang lain. Jika tingkat signifikansi berada di atas 0,05 maka model regresi ini bebas dari masalah heteroskedasitas. Berdasarkan hasil uji heteroskedastisitas pada penelitian ini diperoleh nilai signifikansi masing-masing variabel lebih besar dari 0,05 yang berarti variabel tersebut bebas heteroskedasitas.

Uji multikolinearitas digunakan untuk menguji apakah pada model regresi ditemukan adanya korelasi antar variabel bebas (independen). Apabila terjadi korelasi, maka terdapat multikolinearitas. Multikolinearitas dapat dilihat dari nilai tolerance dan variance inflation factor (VIF), suatu model regresi yang bebas dari masalah multikolinearitas apabila mempunyai nilai toleransi $\geq 0,10$ dan nilai VIF $\leq 10$. Hasil uji multikolinearitas pada penelitian ini menunjukkan nilai tolerance pada masing-masing variabel lebih besar dari 10 persen $(0,1)$, demikian pula dengan nilai VIF masingmasing variabel yang lebih kecil dari 10. Hal ini berarti model regresi bebas dari masalah multikolinearitas. 
Tabel 3.

Hasil Uji Analisis Regresi Linear Berganda

\begin{tabular}{|c|c|c|c|c|c|c|}
\hline \multirow[t]{2}{*}{ Keterangan } & \multicolumn{2}{|c|}{$\begin{array}{c}\text { Unstandardized } \\
\text { Coefficients }\end{array}$} & \multirow{2}{*}{$\begin{array}{c}\begin{array}{c}\text { Standardized } \\
\text { Coefficients }\end{array} \\
\text { Beta } \\
\end{array}$} & \multirow[t]{2}{*}{$\mathbf{T}$} & \multirow[t]{2}{*}{ Sig. } & \multirow[t]{2}{*}{$\begin{array}{l}\text { Hasil Uji } \\
\text { Hipotesis }\end{array}$} \\
\hline & B & Std. Error & & & & \\
\hline (Constant) & $-0,448$ & 1,035 & & $-0,433$ & 0,667 & \\
\hline Kuaaitas SIA $\left(\mathrm{X}_{1}\right)$ & 0,269 & 0,077 & 0,268 & 3,497 & 0,001 & $\mathrm{H}_{1}$ Diterima \\
\hline Norma Subyektif $\left(\mathrm{X}_{2}\right)$ & 0,278 & 0,064 & 0,334 & 4,336 & 0,000 & $\mathrm{H}_{2}$ Diterima \\
\hline Kemudahan & 0,729 & 0,121 & 0,456 & 6,013 & 0,000 & $\mathrm{H}_{3}$ Diterima \\
\hline \multicolumn{7}{|l|}{ Penggunaan $\left(\mathrm{X}_{3}\right)$} \\
\hline$R$ & & 0,899 & & & & \\
\hline$R$ Square & & 0,809 & & & & \\
\hline Adjusted R Square & & 0,799 & & & & \\
\hline F Hitung & & 78,968 & & & & \\
\hline Sig. $F$ & & 0,000 & & & & \\
\hline
\end{tabular}

Sumber: Data diolah, 2018

Nilai konstanta $(\alpha)$ sebesar - 0,448 menyatakan bahwa jika nilai kualitas SIA $\left(\mathrm{X}_{1}\right)$, norma subyektif $\left(\mathrm{X}_{2}\right)$ dan kemudahan penggunaan konstan, maka nilai kinerja individu $(\mathrm{Y})$ menurun sebesar 0,448 satuan. Nilai koefisien $\left(\beta_{1}\right)$ sebesar 0,269 menunjukkan bahwa apabila nilai Kualitas SIA $\left(\mathrm{X}_{1}\right)$ meningkat satu satuan, dengan asumsi variabel lain konstan, maka nilai kinerja individu (Y) akan meningkat sebesar 0,269 satuan. Nilai koefisien $\left(\beta_{2}\right)$ sebesar 0,278. Nilai koefisien ini menunjukkan bahwa apabila nilai norma subyektif $\left(\mathrm{X}_{2}\right)$ meningkat satu satuan, maka nilai kinerja individu (Y) akan meningkat sebesar 0,278 satuan dengan asumsi variabel lain konstan. Nilai koefisien $\left(\beta_{3}\right)$ sebesar 0,729 . Nilai koefisien ini menunjukkan bahwa apabila nilai kemudahan penggunaan (X3) meningkat satu satuan, maka nilai kinerja individu (Y) akan meningkat sebesar 0,729 satuan dengan asumsi variabel lain konstan.

Hasil pengujian pada Tabel 3. menunjukkan bahwa koefisien determinasi yaitu nilai Adjusted $R$ Square sebesar 0,799. Ini berarti sebesar 79,9 persen variabel kualitas SIA $\left(\mathrm{X}_{1}\right)$, norma subyektif $\left(\mathrm{X}_{2}\right)$ dan kemudahan penggunaan $\left(\mathrm{X}_{3}\right)$ 
menjelaskan variasi dari kinerja individu (Y), sedangkan sisanya sebesar 20,1 persen dipengaruhi oleh faktor lainnya. Berdasarkan Tabel 3. diperoleh nilai $\mathrm{F}$ hitung sebesar 78,968 dengan tingkat signifikansi sebesar 0,000. Karena signifikansi F hitung lebih kecil dari 0,05, maka dapat disimpulkan bahwa model regresi yang digunakan untuk menguji pengaruh variabel independen terhadap variabel dependen layak digunakan.

Berdasarkan Tabel 3. di atas dapat dilihat bahwa nilai t hitung kualitas SIA $\left(\mathrm{X}_{1}\right)$ sebesar 3,497 dengan tingkat signifikansi sebesar 0,001 lebih kecil dari $\alpha=$ 0,05. Hasil ini menunjukan bahwa Kualitas SIA berpengaruh positif signifikan terhadap kinerja individu. Dengan demikian maka $\mathrm{H}_{1}$ diterima. Kualitas Sistem Informasi Akuntansi pada suatu perusahaan akan mempengaruhi kinerja individu di perusahaan tersebut. Rahmawati $(2008 ; 107)$ menyatakan sistem informasi akuntansi dapat digunakan untuk meningkatkan kecepatan, fleksibilitas, integritas, dan keakuratan informasi yang dihasilkan, dengan demikian banyak pihak yang memanfaatkan sistem informasi akuntansi untuk mencapai keunggulan perusahaan melalui kinerja karyawannya. Hasil penelitian ini konsisten dengan penelitian yang dilakukan oleh Delone dan Mclean (1992) serta Arifin dan Pratolo (2012) yang menemukan bahwa kualitas sistem informasi berdampak positif pada kinerja individu.

Berdasarkan Tabel 3. di atas dapat dilihat bahwa nilai t hitung norma subyektif $\left(\mathrm{X}_{2}\right)$ sebesar 4,336 dengan tingkat signifikansi sebesar 0,000 lebih kecil dari $\alpha=0,05$. Hasil ini menunjukan bahwa norma subyektif berpengaruh positif 
Ni Luh Made Galih Putri Saraswati dan I Gusti Ayu Eka Damayanthi. Pengaruh ...

signifikan terhadap kinerja individu. Dengan demikian maka $\mathrm{H}_{2}$ diterima. Normanorma subyektif (subjective norms) adalah pengaruh sosial yang mempengaruhi seseorang untuk berperilaku. Seseorang akan memiliki keinginan terhadap suatu obyek atau perilaku seandainya ia terpengaruh oleh orang-orang di sekitarnya untuk melakukannya atau ia meyakini bahwa lingkungan atau orang-orang disekitarnya mendukung terhadap apa yang ia lakukan. Pernyataan tersebut didukung dengan hasil penelitian ini dimana norma subyektif berpengaruh positif terhadap kinerja individu. Penelitian ini konsisten dengan hasil penelitian yang dilakukan oleh Thompson et al (1991), Rahmi Qadri (1997) dan Thai Fung Jin (2002) yang menyatakan norma subyektif berpengaruh positif signifikan terhadap kinerja individu.

Berdasarkan Tabel 3. di atas dapat dilihat bahwa nilai t hitung kemudahan penggunaan $\left(\mathrm{X}_{3}\right)$ sebesar 6,013 dengan tingkat signifikansi sebesar 0,000 lebih kecil dari $\alpha=0,05$. Hasil ini menunjukan bahwa kemudahan penggunaan berpengaruh positif signifikan terhadap kinerja individu. Dengan demikian maka $\mathrm{H}_{3}$ diterima. Penerapan Sistem Informasi Akuntansi berbasis teknologi serta didukung dengan kemampuan teknik pemakai yang baik, mampu memaksimalkan efektivitas dari sistem tersebut. Sistem yang efektif adalah sistem yang mampu memberikan manfaat kepada penggunanya (Pardani dan Damayanthi, 2017). Dengan kemampuan untuk menerapkan sistem individu akan merasa mudah dalam menggunakan sistem yang ada maka mampu membantu individu dalam menyelesaikan pekerjaannya sehingga berefek pada peningkatan kinerja. 
Penelitian ini konsisten dengan hasil penelitian yang dilakukan oleh $\mathrm{Gu}$ (2012), Dewi dan Dharmadiaksa (2017), Alannita dan Suaryana (2014), dan Mahendra dan Widhiani (2016) yang menyatakan kemampuan teknik pemakai berpengaruh positif signifikan terhadap kinerja individu.

\section{SIMPULAN}

Berdasarkan hasil analisis yang diperoleh dalam penelitian ini, maka dapat disimpulkan sebagai berikut: 1) Kualitas Sistem Informasi Akuntansi berpengaruh positif terhadap Kinerja Individu di Perusahaan Agung Bali Oleh-Oleh. Artinya dengan diterapkannya Sistem Informasi Akuntansi yang berkualitas di Perusahaan Agung Bali Oleh-Oleh, maka mampu meningkatkan kinerja individu di perusahaan tersebut; 2) Norma subyektif berpengaruh positif terhadap Kinerja Individu di Perusahaan Agung Bali Oleh-Oleh. Artinya dengan memperhatikan norma subyektif berupa dukungan dari lingkungan sekitar dalam operasional perusahaan Agung Bali Oleh-Oleh, maka mampu mendorong individu untuk menggunakan sistem informasi akuntansi berbasis tenologi yang mampu meningkatkan kinerja individu di perusahaan tersebut; 3) Kemudahan Penggunan berpengaruh positif terhadap Kinerja Individu di Perusahaan Agung Bali OlehOleh. Artinya dengan kemampuan teknik pemakai yang baik individu akan lebih mengusai dan merasa mudah dalam menggunakan Sistem Informasi Akuntansi yang ada serta teknologi penunjang yang digunakan, sehingga akan mampu meningkatkan kinerja individu tersebut. 
Ni Luh Made Galih Putri Saraswati dan I Gusti Ayu Eka Damayanthi. Pengaruh ...

Berdasarkan simpulan diatas, saran yang dapat direkomendasikan bagi peneliti selanjutnya diharapkan dapat meneliti pada bidang usaha lainnya sehingga hasil penelitian dapat digeneralisasikan. Hal ini dikarenakan hasil penelitian mungkin saja berbeda jika diterapkan pada bidang usaha lainnya, sehingga hasil penelitian dapat dibandingkan nantinya dengan penelitian sebelumnya. Peneliti selanjutnya juga dapat menambahkan variabel moderasi atau variabel bebas lainnya.

\section{REFERENSI}

Ajzen, I., dan Fishbein, M., 1980. Understanding Attitudes and Predicting Social Behavior, Prentice-Hall, Eanglewood Scliffs, NJ.

Alannita, Ni Putu. Dan Suaryana, Gusti Ngurah Agung. 2014. Pengaruh Kecanggihan Teknologi Informasi, Partisipasi Manajemen, dan Kemampuan Teknik Pemakai Sistem Informasi Akuntansi pada Kinerja Individu. E-Jurnal Akuntansi Universitas Udayana, h: 33-45.

Al-kasswna, Reem Okab. 2012. Study and Evaluation of Government Electronic Accounting Information Systems - a Field Study in the Hashemite Kingdom of Jordan. Research Journal of Finance and Accounting. Vol 3: 4.

Alles, Michael G., Alexander Kogan, and Mikos A. Vasarhelyi. 2008. Exploiting Comparative Advantage: A Paradigm for Value Added Research in Accounting Information Systems. International Journal of Accounting Information Systems. 9: 202-215.

Alrabei, Ali Mahmoud Abdallah. 2014. The Impact of The Accounting Information System on the Islamic Banks of Jordan: an Empirical Study. Europe Scientific Journal. 10 (4).

Bodnar, George H dan Hopwood, William S. 2006. Sistem Informasi Akuntansi, Edisi 9. Andi: Yogyakarta

Davis, F.D., 1989, 'Perceived Usefulness Perceived Ease of Use, and User Acceptance of Information Technology' dalam MIS Quarterly, VOL. 13, No. 3, hal 319-340 
Delone, W. H, and Mclean, E. R. 1992. Information System Success: The Quest for the zdependent Variable. Information System Research, 3(1): 60-95.

Dewi, Ni Luh Ayu Artha. Dan Dharmadiaksa, Ida Bagus. 2017. Pengaruh Efektivitas Sistem Informasi Akuntansi, Pemanfaatan Teknologi Informasi dan Kemampuan Teknis Pemakai Sistem Informasi Akuntansi Terhadap Kinerja Individu pada Koperasi Simpan Pinjam di Kabupaten Karangasem. E-Jurnal Akuntansi Universitas Udayana. hal 5-6.

Dita, Made Ambara dan Putra, I Wayan. 2016. Pengaruh Penerapan Sistem Informasi Akuntansi, terhadap Kinerja Karyawan dengan Integritas Karyawan sebagai Variabel Pemoderasi. E-Jurnal Akuntansi Universitas Udayana. 15: 614-640.

Ghozali, Imam. 2003. Aplikasi Analisis Multivariate dengan Program SPSS 21. Semarang : Badan Penerbit Universitas Diponegoro.

Grande, Elena Urquaia. 2011. The Impactof Accounting Information Systems (AIS) on Performance measures: Empirical evidence in Spanish SMEs1. The International Journal of Digital Accounting Research, 11(2): h: 2543.

Hall, James A. 2009. Sistem Informasi Akuntansi. Salemba Empat: Jakarta

Jogiyanto, 2007, Sistem Informasi Keprilakuan, Andi Offset Yogyakarta.

Kharuddin, S., M.Z. Ashari, \& Nassir, M.A. 2010. Information System and Firms Performance: The Case of Malaysian Small Medium Enterprises. International business research, 3(4), pp: 33.

Mahendra, I Gede Aditya. Dan Widhiyani, Ni Luh Sari. 2015. Kemampuan Teknik Pemakai Memoderasi Pengaruh Efektivitas Sistem Informasi Akuntansi pada Kinerja Individual Koperasi Simpan Pinjam di Kecamatan Tabanan. E-Jurnal Akuntansi Universitas Udayana. h: 4.

Pardani, Kadek Kusuma. Dan Damayanthi, I Gusti Ayu Eka 2017. Pengaruh Pemanfatan Teknologi Informasi, Partisipasi Pemakai, Dukungan Manajemen Puncak dan Kemampuan Teknik Pemakai Sistem Informasi Akuntansi Terhadap Efektivitas Sistem Informasi Akuntansi pada Koperasi Simpan Pinjam di Kecamatan Tabanan. SkripsiS-1 Jurusan Akuntansi Universitas Udayana 
Ni Luh Made Galih Putri Saraswati dan I Gusti Ayu Eka Damayanthi. Pengaruh ...

Rahmawati, Diana. 2008. Analisis Faktor-Faktor yang Barpengaruh Terhadap Pemanfaatan Teknologi Informasi. Jurnal Ekonomi dan Pendidikan , 5 (1), h: 107:118.

Ramdhani, Neila. 2009. Model Perilaku Penggunaan TIK "NR2007" Pengembangan dari Technology Acceptance Model (TAM). Jurnal Fakultas Psikologi Universitas Gajah Mada. Vol 17, No. 1: hal 17-27

Romney B. Marshall dan Steinbart, Paul John. 2015. Sistem Informasi Akuntansi. Salemba Empat. Jakarta.

Sugiyono. 2016. Metode Penelitian Bisnis. Bandung: CV Alfabeta

Thai Fung Jin. 2002. Analisis Faktor-Faktor yang Mempengaruhi Pemanfaatan Teknologi Informasi dan Pengaruh Pemanfaatan Teknologi Informasi Terhadap Kinerja Akuntan Publik. E-Jurnal Universitas Gajah Mada.

Thompson Ronald L., Christoper A. and Howell Jane M. 1991. Personal Computing : Toward a Conceptual Model of Utilization. MIS Quarterly March: 125-143.

Utama, Made Suyana. 2014. Aplikasi Analisis Kuantitatif, Edisi kedelapan: Denpasar.

Yao, Lee J, et al. 2010. The Influence of Firm Specific Context on Realizing Information Technology Business Value in Manufacturing Industry. International Journal of Accounting Information Systems. 11: 353-362. 